\title{
Influência do Gene Halotano sobre a Qualidade da Carne Suína ${ }^{1}$ \\ Paulete de Oliveira Vargas Culau², Jorge López ${ }^{3}$, Jane Maria Rubensam ${ }^{4}$, Rui Fernando Félix Lopes ${ }^{5}$, Sérgio Nicolaiewsky ${ }^{6}$
}

\begin{abstract}
RESUMO - O objetivo deste trabalho foi avaliar o efeito do gene halotano sobre as características de qualidade da carne suína. Foram utilizadas 151 carcaças de suínos híbridos comerciais, sendo 93 carcaças com genótipo halotano normal (Hal $\left.{ }^{\mathrm{NN}}\right), 51$ heterozigotas $\left(\mathrm{Hal}^{\mathrm{Nn}}\right)$ e 7 recessivas $\left(\mathrm{Hal}^{\mathrm{nn}}\right)$. As medidas efetuadas foram peso da carcaça, refletância através da fibra óptica GP4-Hennessy, temperatura muscular aos 45 minutos e pH aos 45 minutos e 24 horas após o abate no músculo Longissimus dorsi, cor e identificação do genótipo halotano em amostras de gordura através de PCR-RFLP. Houve diferença significativa entre suínos $\mathrm{Hal}^{\mathrm{Nn}}$ e Hal ${ }^{\mathrm{NN}}$ e entre $\mathrm{Hal}^{\mathrm{nn}}$ e Hal ${ }^{\mathrm{NN}}$ quanto ao $\mathrm{pH}$ inicial e a cor. Em relação à temperatura muscular e pH, final não houve diferença significativa entre os genótipos. A freqüência de carcaças PSE foi mais elevada nos suínos $\mathrm{Hal}^{\mathrm{nn}}$ e $\mathrm{Hal}^{\mathrm{Nn}}$ do que nos suínos $\mathrm{Hal}^{\mathrm{NN}}(85,71 ; 58,82$ e 36,56\%,

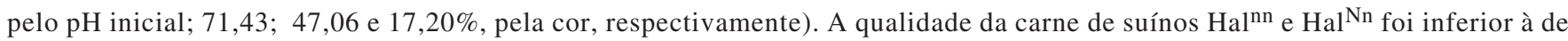
suínos $\mathrm{Hal}^{\mathrm{NN}}$, em termos de $\mathrm{pH}$ e cor.
\end{abstract}

Palavras-chave: gene halotano, pse, qualidade da carne suína

\section{Effect of the Halothane Gene on the Quality of Pork}

\begin{abstract}
The aim of this research work was to evaluate the effect of the halothane gene on the quality characteristics of pork. Commercial hybrid pork carcasses (151) were used for the trial, 93 with normal halothane genotype (Hal ${ }^{\mathrm{NN}}$ ), 51 heterozygous genotype $\left(\mathrm{Hal}^{\mathrm{Nn}}\right)$ and 7 homozigous recessive genotype $\left(\mathrm{Hal}^{\mathrm{nn}}\right)$. The measured attributes were carcass weight, muscle temperature at 45 minutes and $\mathrm{pH}$ at 45 minutes and 24 hours after the slaughter at the Longissimus dorsi muscle and color. Identification of the halothane genotype was determined in fat samples through the PCR-RLPC technique. Significant differences were observed between $\mathrm{Hal}^{\mathrm{Nn}}$ and $\mathrm{Hal}^{\mathrm{NN}}$ and between $\mathrm{Hal}^{\mathrm{nn}}$ and $\mathrm{Hal}^{\mathrm{NN}}$ pigs in relation to the inicial $\mathrm{pH}$ and color of the meat. The PSE carcasses frequency was greater in the Hal ${ }^{\mathrm{nn}}$ and in the $\mathrm{Hal}^{\mathrm{Nn}}$ pigs than in the $\mathrm{Hal}^{\mathrm{NN}}(85.71,58.82$, and 36,56\%, based on the initial $\mathrm{pH} ; 71.43,47.06$, and $17.20 \%$, based on color, respectively). The halothane genotype did not affect muscle temperature and final $\mathrm{pH}$. Related to $\mathrm{pH}$ and color, the quality of pork was inferior in the $\mathrm{Hal}^{\mathrm{nn}}$ and the $\mathrm{Hal}^{\mathrm{Nn}}$ pigs than in the $\mathrm{Hal}^{\mathrm{NN}}$.
\end{abstract}

Key Words: halothane gene, pork quality, pse

\section{Introdução}

Alguns suínos são extremamente sensíveis ao estresse. Nestes animais ocorre uma síndrome (PSS - Porcine Stress Syndrome) que é desencadeada por fatores como, por exemplo: o desmame, exercícios, cópula, mistura com outros animais, transporte e manejo pré-abate.

Devido à elevada produção de calor nos animais que desenvolvem a síndrome, esta também é denominada Hipertermia Maligna (Maclennan \& Phillipe, 1992).

O gene halotano, além de determinar a maior predisposição ao estresse em suínos, é responsável pela produção de carcaças com maior produção de carne magra, porém relacionado à produção de carne PSE (do inglês: pale, soft and exudative), um problema grave para a industrialização de carnes.

Fujii et al. (1991) encontraram uma mutação no gene que codifica para o receptor rianodina do músculo esquelético, correlacionada com a hipertermia maligna. Os autores desenvolveram um teste não invasivo, baseado em PCR-RFLP (reação em cadeia de polimerase - polimorfismos do comprimento dos fragmentos de restrição), que permite diferenciar três genótipos: HalNN (normal, dominante), HalNn (heterozigoto) e Halnn (sensível, recessivo) e com este material é possível, atualmente, fazer estudos de freqüência do gene halotano, nas diferentes raças de

\footnotetext{
${ }_{1}^{1}$ Parte da tese de doutorado em Zootecnia do primeiro autor.

2 Médico Veterinário, Doutor, Prof. Adjunto do ICBS, UFRGS. Moema 444, Chácara das Pedras, CEP: 91330-500, Porto Alegre-RS. E.mail: anavet@vortex.ufrgs.br

${ }^{3}$ Engenheiro-Agrônomo, Ph D., Prof. Titular da Faculdade de Agronomia, UFRGS. E.mail: jlopez@orion.ufrgs.br

${ }^{4}$ Médico Veterinário, Doutor, Prof. Adjunto da Faculdade de Veterinária, UFRGS. E.mail: jane@orion.ufrgs.br

5 Médico Veterinário, Doutor, Prof. Adjunto do ICBS, UFRGS. E.mail: rfopes@ dna.cbiot.ufrgs.br

${ }^{6}$ Engenheiro Agrônomo, Mestre, Prof. Adjunto da Faculdade de Agronomia, UFRGS. E.mail: nicola@vortex.ufrgs.br
} 
suínos, para que melhores estratégias de cruzamentos sejam traçadas.

A carne de suínos heterozigotos (HalNn) apresenta-se caracterizada pela baixa retenção de água, cor pálida e alta incidência de PSE quando comparada com a de suínos normais (HalNN) (Lundstrom et al., 1989; Simpson \& Webb, 1989; Sather et al., 1991).

Mesmo que exista correlação significativa entre animais portadores do gene halotano e produção de carne PSE (Silveira, 1996), é afirmado que o genótipo por si só não explica totalmente a ocorrência de carne PSE (Warris, 1995).

Culau et al. (1994) identificaram freqüência de $30,69 \%$ de carcaças PSE no estado do Rio Grande do Sul, por leitura de $\mathrm{pH}$ inicial no músculo Longissimus dorsi, em 8842 carcaças suínas. A identificação da causa desta freqüência alta de carcaças PSE, entretanto, não está definida, visto que muitos fatores ambientais e genéticos podem estar influenciando.

Pommier \& Houde (1993) encontraram, no grupo de animais produtores de carne normal, $88,4 \%$ de animais normais $(\mathrm{NN}), 11 \%$ de animais heterozigotos (Nn) e 0,6\% de animais recessivos (nn). Em contrapartida, no grupo de animais produtores de carne PSE, 67\% provieram de animais normais $(\mathrm{NN})$, $28,7 \%$ de heterozigotos $(\mathrm{Nn})$ e $3,6 \%$ de animais recessivos (nn). Levando-se em consideração a frequiência dos genótipos na população, os autores concluíram que nem toda carne PSE é causada pela síndrome do estresse suíno, mas muitos dos indivíduos recessivos produzem carne PSE. O mesmo foi sugerido por Murray (1994) para o qual a remoção da mutação da população de suínos, no Canadá, poderia baixar a freqüência de carne PSE de $20 \%$ para apenas $16,5 \%$, indicando que a maioria dos problemas de PSE não pode ser atribuída a este defeito genético. Dependendo do manejo pré-abate, entre 10 e $63 \%$ dos animais $\mathrm{Nn}$ e entre 25 e $85 \%$ dos animais $\mathrm{nn}$ produzem carne PSE e, segundo o autor, esta é uma variação muito grande.

Na Austrália, Trout (1994) mostrou que, em carcaças com escores baixos de PSE, houve pouca relação entre a freqüência do gene halotano e incidência de carne PSE. Somente 13\% destas carcaças foram homozigotas recessivas (nn) ou heterozigotas (Nn) para o gene halotano. Ao contrário, dos suínos que apresentaram altos escores de PSE, mais de $40 \%$ possuíam genótipo nn ou Nn. O autor concluiu que o gene halotano é um dos fatores de maior contribuição somente em casos severos de PSE. Carnes com PSE menos intenso podem ser originadas, provavelmente, por mau manejo pré-abate ou processamento pósabate inadequado.

O genótipo halotano, segundo Smet et al. (1996), foi o fator predominante determinando a qualidade da carne em relação à condição PSE. Através destes estudos, suínos recessivos para o gene halotano (nn) foram sempre significativamente diferentes dos suínos heterozigotos para o gene halotano $(\mathrm{Nn})$ e dos suínos normais para o gene halotano (NN). Para pH inicial e perda de líquido por gotejamento, suínos do genótipo halotano Nn e NN diferiram significativamente, sendo o pH inicial mais baixo nos suínos heterozigotos $(\mathrm{Nn})$, cuja carne também apresentou uma maior perda de líquido. Diferenças entre raças (Landrace Belga e Piétrain) e entre sexos (fêmeas e castrados) não foi importante quando comparado com o efeito do genótipo halotano.

$\mathrm{O}$ pH inicial da carne de suínos heterozigotos (Nn) foi inferior a dos suínos normais para o gene halotano no trabalho de Sather \& Jones (1996), sugerindo que animais com genótipo halotano $\mathrm{Nn}$ tiveram tendência em produzir mais carne PSE, enfatizando que, com o aumento das carcaças heterozigotas $(\mathrm{Nn})$, reduziu-se a qualidade da carne e questionou-se o mérito do uso do gene halotano.

Os resultados de Smet et al. (1998) mostraram que a qualidade da carne de suínos heterozigotos não é melhor do que a de suínos sensíveis ao estresse (nn), quando abatidos nas mesmas condições.

Tam et al. (1998) observaram, em relação à coloração da carne, que suínos heterozigotos e homozigotos recessivos para o gene halotano apresentavam uma coloração mais clara do que suínos normais $(p<0,05)$. Os mesmos autores verificaram um $\mathrm{pH}$ inicial mais baixo $(\mathrm{p}<0,05)$ em carcaças do genótipo halotano Nn e nn comparadas com o genótipo halotano NN. Uma relação extremamente negativa entre $\mathrm{pH}$ inicial e genótipo halotano foi encontrada. Com o aumento da freqüência do alelo n no genótipo halotano o $\mathrm{pH}$ inicial ficou mais baixo.

Não houve diferença entre os três genótipos em relação, à medida de $\mathrm{pH}$ final da carne nos trabahos de Smet et al. (1998) e Tam et al. (1998).

O objetivo deste trabalho foi identificar nas carcaças com problemas de qualidade da carne se a razão deste defeito é genética ou ambiental e qual a frequiência da ocorrência.

O termo "qualidade da carne" usado neste trabalho refere-se à ocorrência de carne suína normal e carne PSE. 


\section{Material e Métodos}

O trabalho foi realizado no matadouro-frigorífico Avipal, em Lajeado, RS e as análises laboratoriais foram desenvolvidas no Laboratório de Inspeção de Carnes da Faculdade de Veterinária e no Laboratório de Biotecnologia Animal, no Centro de Biotecnologia, ambos da Universidade Federal do Rio Grande do Sul, Porto Alegre, RS.

Foram utilizadas meia-carcaças direitas de 151 suínos híbridos comerciais provenientes de cruzamentos das raças Landrace, Large White e Duroc. Os animais permaneceram no frigorífico em torno de 18 horas em dieta hídrica e foram abatidos com insensibilização por eletronarcose. A coleta de dados foi realizada em três etapas representadas por três dias de abate. Dos animais abatidos, foram escolhidas na linha de abate 31, 50 e 70 carcaças, respectivamente, no primeiro, segundo e terceiro dia de abate. A seleção das carcaças foi realizada com o auxílio da sonda eletrônica "GP4-Hennessy". Para cada carcaça com alteração (PSE) detectada pela sonda, foi selecionada uma carcaça imediatamente posterior sem alteração (normal), assim as carcaças com alterações foram pareadas com carcaças sem alterações, com o objetivo de detectar um número maior de animais com genótipo halotano HalNn e Halnn.

Após serem tipificadas eletronicamente por meio do "GP4-Hennessy", as carcaças foram pesadas e resfriadas por 24 horas à temperatura entre 0 e $2^{\circ} \mathrm{C}$. $\mathrm{Na}$ câmara de resfriamento foram realizadas as leituras de $\mathrm{pH}$ e temperatura muscular.

Das carcaças que seguiram para o espostejamento foi separado o lombo e foram retiradas chuletas para as leituras de cor e coleta de amostra de gordura para determinação do genótipo.

As medidas de $\mathrm{pH}$ foram realizadas no músculo longo torácico, na altura da décima costela, aos 45 minutos ( $\mathrm{pH}$ inicial) e 24 horas após o abate ( $\mathrm{pH}$ final). Foi utilizado um aparelho portátil marca Jenway (3071), com eletrodo combinado de vidro tipo espada, de inserção, marca Analion, modelo V-627-c. As carcaças com valores de $\mathrm{pH}$ inicial inferiores a 5,8 foram consideradas PSE, sendo que para valores de $\mathrm{pH}$ inferiores a 5,6 estas foram consideradas PSE extremo. A temperatura foi medida no músculo longo torácico na altura da décima costela, aos 45 minutos após o abate, utilizando-se termômetro acoplado ao aparelho medidor de $\mathrm{pH}$.

A avaliação da cor foi realizada na chuleta, com auxílio de padrões fotográficos da Polyfilm - Divisão de Carnes, com cinco tonalidades de músculo longo dorsal, respectivamente, rosa muito pálido (1), rosa pálido (2), rosa cinzento (3), vermelho escuro (4) e vermelho muito escuro (5), conforme Ourique (1989). As amostras de carne com coloração igual a 2,5 ou superior foram consideradas normais. Amostras de carne com coloração inferior a 2,5 foram consideradas PSE, sendo que amostras com coloração inferior a 2,0 foram consideradas PSE extremo.

Para a determinação do genótipo halotano utilizou-se um par de oligonucleotídeos específico (MH F:5'-GTTCCCTGTGTGTGTGCAATGGTG-3' e MH-R:5 e ATCTCTAGAGCCAGGGAGCAAG TTCTCAGTAAT-3') para a amplificação da seqüência de DNA do gene do receptor rianodina suíno (Fujii et al., 1991). Alíquotas de gordura de 30 a 50 mg de cada amostra de carne suína foram colocadas em tubos e foram adicionados $200 \mathrm{~mL}$ de tampão 1XPCR com $1,6 \mathrm{mg} / \mathrm{mL}$ de Proteinase K (GIBCOBRL, 25530-015), sendo incubadas a $56^{\circ} \mathrm{C}$ por 150 minutos e a $95^{\circ} \mathrm{C}$ por 20 minutos.

Após a incubação, $2 \mathrm{~mL}$ de cada amostra foram adicionados a tubos com $8 \mathrm{~mL}$ de uma solução contendo: $1 \mathrm{~mL}$ tampão 10XPCR (20 mM MgCl2, $500 \mathrm{mM} \mathrm{KCl}$, 100 mM Tris-HCl pH 8,3); $1 \mathrm{~mL}$ da solução com 1,25 mM de cada dNTP; 4 mg de BSA (Cenbiot $\left.{ }^{\circledR} / \mathrm{RS}\right)$; $0,5 \mathrm{U}$ de Taq-DNA polimerase (Cenbiot $\left.{ }^{\circledR} / \mathrm{RS}\right)$; 10 pmoles de cada oligonucleotídeo; e água ultrapura estéril. As amostras contendo o volume de $10 \mathrm{~mL}$ para reação e $30 \mathrm{~mL}$ de óleo mineral $\left(\operatorname{Sigma}{ }^{\circledR}\right.$, M-5904) foram acondicionadas no termociclador automático e submetidas ao seguinte protocolo de amplificação por PCR: a) $94^{\circ} \mathrm{C}$ por 5 minutos; b) 40 ciclos consecutivos de $94^{\circ} \mathrm{C}$ por 1 minuto, $56^{\circ} \mathrm{C}$ por 30 segundos e $72^{\circ} \mathrm{C}$ por 1 minuto; e c) $72^{\circ} \mathrm{C}$ por 8 minutos.

Após a amplificação do DNA de gordura suína por PCR, foram adicionados a cada amostra $10 \mathrm{U}$ de enzima Hha I, $2 \mathrm{~mL}$ de tampão de reação 10X Hha I e de água ultra pura estéril, perfazendo um volume final de $20 \mathrm{~mL}$. Os tubos foram submetidos a incubação a $37^{\circ} \mathrm{C}$ por 90 minutos e $65^{\circ} \mathrm{C}$ por 10 minutos. Os $20 \mathrm{~mL}$ de amostra contendo o DNA amplificado por PCR e submetidos ao ensaio de restrição com Hha I foram levados à eletroforese em gel de agarose 3\% em tampão TBE 0,5X (Sambrook et al., 1989).

A digestão do fragmento com a enzima de restrição Hha I produz dois fragmentos de 49 e $32 \mathrm{pb}$ para animais homozigotos normais (HalNN), três fragmentos de 49, 32 e 81 pb para heterozigotos (HalNn) e somente um fragmento de $81 \mathrm{pb}$ para indivíduos homozigotos mutantes (Halnn). 
A análise estatística foi realizada com o programa estatístico SAS versão 6.11 (PROC. GLM), tendo como co-variável o peso da carcaça e como tratamento as classificações obtidas pela fibra óptica GP4-Hennessy e o genótipo halotano. A comparação entre as médias foi realizada com o procedimento LSMEANS. A análise das freqüências foi realizada por intermédio do teste do Qui-quadrado $\left(\mathrm{x}^{2}\right)$.

\section{Resultados e Discussão}

Em 151 carcaças analisadas com peso aproximado de $70 \mathrm{~kg}$, foram encontradas 93 carcaças provenientes de suínos com genótipo halotano normal $($ HalNN $=61,59 \%), 51$ carcaças de suínos heterozigotos ( $\mathrm{HalNn}=33,77 \%)$ e sete carcaças de suínos com genótipo halotano recessivo para o gene halotano (Halnn $=4,64 \%)$.

$\mathrm{O}$ pH inicial do músculo Longissimus dorsi foi mais baixo nos suínos portadores do gen halotano (HalNn e Halnn), não havendo diferença significativa entre os suínos recessivos e heterozigotos (Tabela 1), concordando com Smet et al. (1998). Entretanto, observou-se diferença significativa $(\mathrm{P}=0,003)$ nos valores de pH inicial do músculo Longissimus dorsi entre os suínos normais $(5,91)$ e heterozigotos $(5,71)$, concordando com Sather e Jones (1996), Smet et al. (1996, 1998) e Tam et al. (1998). Estes resultados mostram que o gene halotano exerce influência sobre o $\mathrm{pH}$ inicial.

A média geral atribuída à cor foi de $2,41 \pm 0,56$, um pouco mais clara do que o escore normal, igual a 3,0 . Conforme mostra a Tabela 1, a chuleta dos suínos portadores do gene halotano foi mais clara $(\mathrm{P}<0,01)$. Porém, não houve diferença estatística entre os escores de cor dos dois genótipos portadores (HalNn e Halnn $)(\mathrm{P}<0,05)$. Estes resultados estão de acordo com Lundstrom et al. (1989), Sather et al. (1991), e Simpson \& Webb (1989), que também encontraram uma coloração mais clara na carne da carcaça de suínos heterozigotos e homozigotos recessivos para o gene halotano do que na dos suínos normais $(\mathrm{P}<0,05)$.

A coloração da carne tornou-se mais pálida ( $\mathrm{P}<0,01)$ com o aumento do número de alelos "n", o que está de acordo com Smet et al. (1998).

A temperatura muscular logo após o abate não mostrou alteração significativa em relação ao genótipo halotano (Tabela 1), concordando com Smet et al. (1996), que também não encontraram diferença na temperatura muscular das carcaças de suínos dos três genótipos halotano.

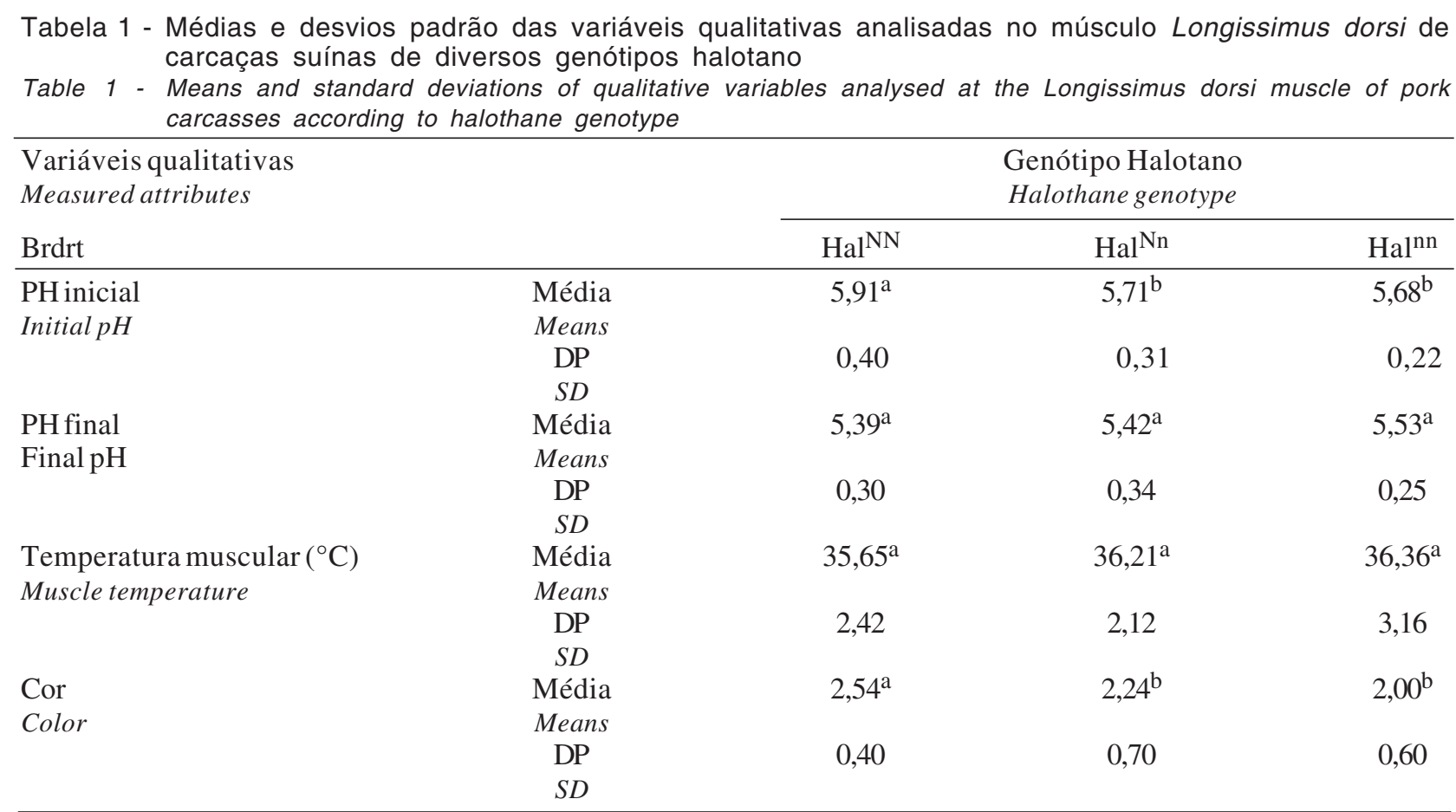

Médias seguidas das mesmas letras, na mesma linha, não diferem estatisticamente em nível de $1 \%$. $\mathrm{DP}=$ desvio padrão.

Means followed by the same letters in the same line don't differ statistically at $1 \%$ level. $S D=$ standard deviation.

R. Bras. Zootec., v.31, n.2, p.954-961, 2002 (suplemento) 
$\mathrm{O}$ pH final das carcaças suínas não diferiu estatisticamente entre os três genótipos halotano (Tabela 1). Este resultado mostrou que a influência do genótipo halotano não está relacionada ao $\mathrm{pH}$ final, concordando com Smet et al. (1998) e Tam et al. (1998).

A freqüência de carcaças PSE $(\mathrm{pH}$ inicial $<5,8)$ foi de $46,36 \%$, uma frequiência elevada e esperada visto que a metade das carcaças selecionadas pela sonda eletrônica foram PSE. Esta freqüência elevada não é uma amostra da freqüência de carcaças PSE deste frigorífico que é bem inferior e nos mostra que a sonda eletrônica teve um bom grau de acerto na identificação de carcaças PSE. Os suínos heterozigotos para o gene halotano apresentaram maior percentagem de carcaças PSE mais PSE extremo $(58,82 \%)$ do que os suínos normais $(36,56 \%)$, tendo sido mais elevada nos suínos recessivos para o gene halotano $(85,71 \%)$ (Figura 1).

A análise do teste qui-quadrado mostrou relação $(\mathrm{P}<0,05)$ do genótipo halotano com a freqüência de carcaças PSE, ou seja, animais portadores (HalNn) ou homozigotos recessivos (Halnn) para o gene halotano tendem a apresentar uma frequiência mais elevada de carcaças PSE. Esta freqüência elevada de carcaças PSE nos suínos heterozigotos, evidenciando a relação de carcaças PSE com o gene halotano concorda com os trabalhos de Pommier \& Houde (1993), Sather \& Jones (1996) e Silveira (1996), para os quais existe forte relação entre os suínos portado-

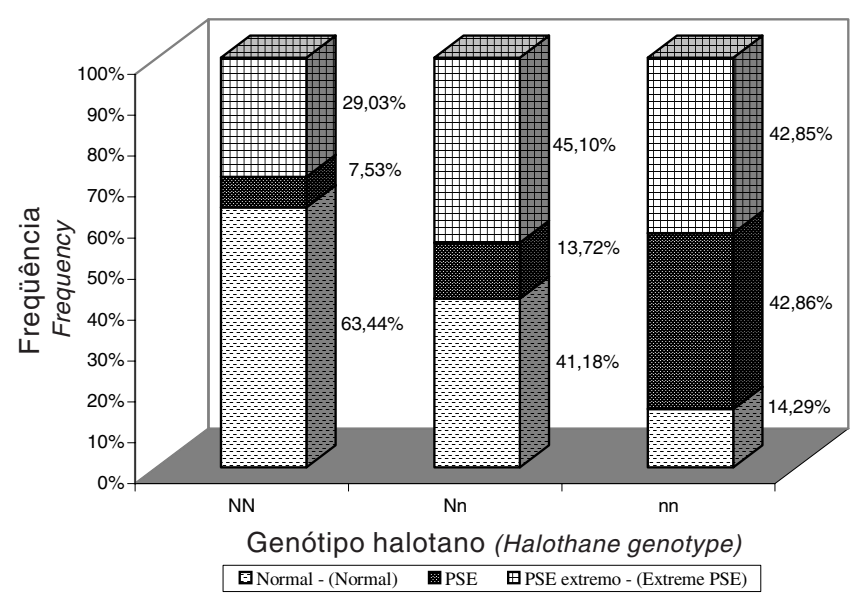

Figura 1 - Freqüência das carcaças normais e PSE em relação ao genótipo halotano conforme leitura de $\mathrm{pH}$ inicial.

Figure 1 - Normal carcasses and PSE frequency as the halothane genotype according to initial $\mathrm{pH}$.

R. Bras. Zootec., v.31, n.2, p.954-961, 2002 (suplemento) res do gene halotano e a condição de carne PSE, com conseqüiente redução da qualidade da carne.

A freqüência de carcaças com condição de extremo PSE (pH inicial menor que 5,6) foi de $35,10 \%$, e mais elevada nos suínos heterozigotos $(45,10 \%)$ do que nos suínos normais $(29,03 \%)$ (Figura 1). A análise do teste qui-quadrado mostra que houve também relação entre o genótipo halotano e a frequiência de carcaças suínas com PSE extremo $(\mathrm{P}<0,05)$. Carcaças de suínos heterozigotos (HalNn) tendem a apresentar uma frequiência mais elevada de carnes PSE extremo. Esta observação concorda com Trout (1994), cujo trabalho revelou que, dos suínos com altos escores de PSE, mais de $40 \%$ foram recessivos ou heterozigotos para o gene halotano. O autor afirmou que o gene halotano é um dos fatores de maior contribuição em casos severos de PSE, mas não para os casos menos severos.

Embora o número de suínos recessivos para o gene halotano seja pequeno $(4,64 \%)$, o que é esperado dentro da população, a freqüência de carcaças PSE observada, nesta população, neste trabalho foi elevada $(85,71 \%)$, sendo igualmente alta a frequiência de carcaças PSE extremo (42,85\%) (Figura 1).

No grupo de animais apresentando carne normal, $72,84 \%$ provieram do grupo de animais homozigotos normais (HalNN), 25,92\% foram oriundos de animais heterozigotos (HalNn) e 1,24\% provenientes de animais recessivos (Halnn). Por outro lado, no grupo de animais produtores de carne PSE, $48,57 \%$ foram pertencentes ao grupo de suínos HalNN, 42,86\% foram heterozigotos e $8,57 \%$, suínos recessivos (Figura 2).

Alguns suínos portadores do gene halotano produziram carne normal e, em contrapartida, observouse que nem todas as características PSE foram causadas pela presença do gene halotano tendo em vista que $48,57 \%$ foram provenientes de animais normais. Porém, $51,43 \%$ das carnes PSE foram resultado da presença do gene halotano, mostrando que o gene, mesmo em heterozigose, teve grande influência na produção de carnes PSE. Estes resultados discordam da conclusão de Pommier \& Houde (1993), para os quais a maior incidência de carnes PSE provém de animais normais (67\%) contra 33\% de animais portadores do gene halotano.

A remoção da mutação da população de suínos, tomando por base este trabalho, poderia reduzir a freqüência de PSE de 46,36\% para 36,56\%, mas não eliminaria o problema. Murray (1994) afirmou que a maioria dos problemas de carnes PSE não poderia ser 


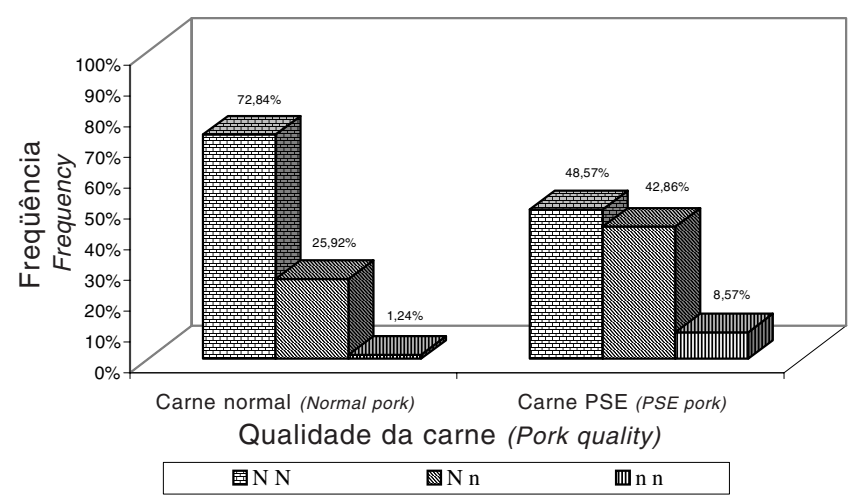

Figura 2 - Freqüência do genótipo halotano em carnes classificadas como normal ou PSE, em função de seu pH inicial.

Figure 2 - Halothane genotype frequency in normal or PSE pork, according to initial $\mathrm{pH}$.

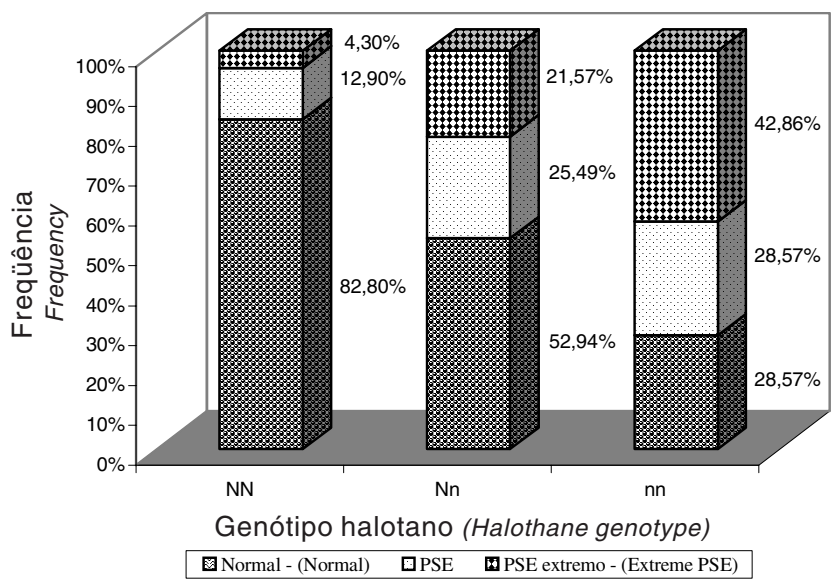

Figura 3 - Freqüência de carcaças normais e PSE em relação ao genótipo halotano, conforme leitura de cor.

Figure 3 - Normal carcasses and PSE frequency as the genotype halothane according to color.

menor, sendo causadas, provavelmente, por problemas de manejo pré-abate, processamento pós-abate, entre outros, conforme assinalou Trout (1994).

Das carcaças com problemas não tão acentuados de PSE (notas atribuídas à cor entre 2,5 e 2,0), $55,55 \%$ foram recessivas (Halnn) ou heterozigotas (HalNn) para o gene halotano. Por outro lado, dos suínos com PSE mais severo, 77,77\% pertenceram ao genótipo Halnn ou HalNn. Estes resultados mostram que o gene halotano é um dos fatores de maior influência quando se trata de casos severos de PSE, o que está de acordo com Trout (1994). Este mesmo autor, porém, não atribuiu grande importância ao gene halotano para casos menos severos de PSE, já que somente $13 \%$ das carcaças por ele analisadas pertenceram ao genótipo Halnn ou HalNn, o que discorda do presente trabalho, em que o gene halotano exerceu também grande influência sobre a produção de carnes PSE com características menos intensas.

No grupo de animais que produziram carne normal foram encontrados $72,64 \%$ de suínos com genótipo normal (HalNN), 25,47\% de animais heterozigotos e $1,89 \%$ de animais com genótipo recessivo (Halnn). Estas freqüências são semelhantes às observadas quando foi utilizada a medida de $\mathrm{pH}$ inicial como variável independente ou como critério de classificação. Em contrapartida, no grupo de animais produtores de carne PSE, 35,56\% tinham genótipo normal sentam carcaças PSE, a intensidade do defeito é 
(HalNN), 53,33\% eram heterozigotos (HalNn) e $11,11 \%$ dos animais eram recessivos (Figura 4).

À semelhança dos resultados obtidos por Pommier \& Houde (1993), observou-se, neste trabalho, que nem toda carne PSE é causada pela presença do gene halotano, isto é, $35,56 \%$ dos animais que produziram carne PSE possuíam genótipo halotano normal. Este resultado indica que carne PSE pode ser provocada em suínos que sofrem manejo pré-abate inadequado ou que os animais estão sendo submetidos a tecnologias de abate que favoreçam a ocorrência do problema. Estas observações estão de acordo com Warris (1995), para o qual o genótipo Haln, por si só, não explica totalmente a produção de carne suína PSE. No entanto, o fato de a freqüência de $64,44 \%$ das carnes PSE estarem relacionadas à presença do gene halotano, sendo 53,33\% provenientes de animais heterozigotos (HalNn), indica que o gene, mesmo em heterozigose, pode ser a principal causa da incidência de carnes PSE, concordando com Silveira (1996).

Segundo Pommier \& Houde (1993), a freqüência de carnes PSE está mais relacionada a fatores préabate do que à freqüência do gene halotano. Os autores afirmaram que nem todo PSE é causado pela Hipertermia Maligna (determinada pela presença do gene halotano). As observações feitas neste trabalho permitem estabelecer a possibilidade de que nem

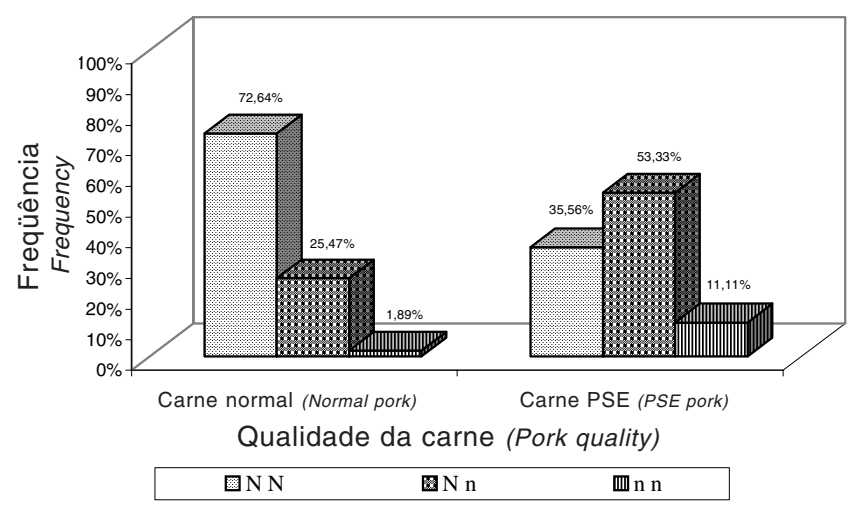

Figura 4 - Freqüências dos genótipos halotano em carnes classificadas como normal ou PSE, em função da cor.

Figure 4 - Halothane genotype frequency in normal or PSE pork, according to color. todo PSE é causado pela presença do gene halotano, mas o fator preponderante para a produção de carne PSE é a presença do gene halotano.

Com base nos resultados obtidos neste trabalho, se fosse removida a mutação genética da população suína e se fosse realizada a tipificação das carcaças utilizando-se como critério de avaliação a cor, a freqüência de carnes PSE poderia ser reduzida de $29,80 \%$ para $17,20 \%$, sendo este um valor ainda muito alto para a incidência de carnes PSE. Esta conceituação concorda com a afirmação de Murray (1994), para quem a maior parte das carnes PSE não se deve a este defeito genético e a remoção desta mutação da população suína diminuiria de $20 \%$ para $16 \%$, mantendo ainda muito alta a incidência de carnes PSE.

$\mathrm{O}$ antagonismo genético entre quantidade e qualidade da carne parece depender da incidência do gene halotano, podendo diferir um pouco entre as medidas de qualidade da carne empregadas.

\section{Conclusões}

A qualidade da carne, proveniente de suínos normais foi superior a dos suínos heterozigotos e recessivos para o gene halotano, porém a qualidade da carne, proveniente de suínos heterozigotos não se mostrou superior a dos suínos recessivos, sensíveis ao estresse (Halnn).

O gene halotano é um dos fatores de maior contribuição em situações mais severas de PSE; todavia, a alta frequiência de carcaças PSE provavelmente não se deva somente ao genótipo halotano, outros fatores como manejo prà9-abate e industrialização também influenciam, principalmente para os suínos com genótipo halotano HalNn e Halnn.

A frequiência de carcaças PSE foi mais elevada nos suínos com genótipo halotano HalNn e HalNn do que nos suínos com genótipo halotano HalNN.

$\mathrm{O}$ pH inicial do músculo Longissimus dorsi foi mais baixo e a cor da carne foi mais pálida nas carcaças de suínos portadores do gene halotano (HalNn e Halnn), não havendo diferença entre elas.

$\mathrm{O} \mathrm{pH}$ final da carne não está relacionado com o genótipo halotano.

A classificação de qualidade de carne com base no $\mathrm{pH}$ inicial é mais rigorosa que aquela baseada na cor, indicando maior incidência da condição PSE. 


\section{Literatura Citada}

CULAU, P.O.V.; OURIQUE, J.M.R.; NICOLAIEWSKY, S. Incidence of PSE in commercial pig carcasses in Rio Grande do Sul state. In: INTERNATIONAL CONGRESS OF MEAT SCIENCE AND TECHNOLOGY, 40., 1994, The Hague. Abstracts... The Hague: ICoMST, 1994. S-IVA.01.

FUJII, J.; OTSU, K.; ZORZATO, F. et al. Identification of a mutation in porcine ryanodine receptor associated with malignant hyperthermia. Science, v.253, n.2, p.448-451, 1991.

LUNSDTRÖM, K.; ESSÉN-GUSTAVSSON, B.; RUNDGREN, M. Effect of halothane genotype on muscle metabolism at slaughter and its relationship with meat quality: a within-litter comparison. Meat Science, v.25, n.1, p.251-263, 1989.

MACLENNAN, D.H.; PHILLIPS, M.S. Malignat hyperthermia. Science, v.256, n.3, p.789-793, 1992.

MURRAY, A. Genetic mutation not answer to PSE problem. International Pigletter, v.14, n.1, p.1-2, 1994.

OURIQUE, J.M.R. Características físico-químicas e organolépticas e suas relações na avaliação de qualidade da carne suína. Porto Alegre: Universidade Federal do Rio Grande do Sul, 1989. 104p. Dissertação (Mestrado em Agronomia - Zootecnia) - Universidade Federal do Rio Grande do Sul, 1989.

POMMIER, S.A.; HOUDE, A. Effect of the genotype for malignant hyperthermia as determined by a restriction endonuclease assay on the quality characteristics of commercial pork loins. Journal of Animal Science, v.71, n.2, p.420-425, 1993.

SAMBROOK, J.; FRITSCH, E.F.; MANIATIS, T. Molecular cloning: a laboratory manual. 2.ed. New York: Cold Spring Harbor Laboratory Press, 1989. v.3. 423p.

SATHER, A.P.; MURRAY, A.C.; ZAWADSKI, S.M. The effect of the halothane gene on pork production and meat quality of pigs reared under commercial condition. Canadian Journal of Animal Science, v.71, n.4, p.959-967, 1991.

SATHER, A.P.; JONES, S.D.M. The effect of genotype on feedlot performance, carcass composition, and lean meat quality from commercial pigs. Canadian Journal of Animal Science, v.76, n.4, p.507-516, 1996.
SILVEIRA, E.T.F. Impacto da qualidade na industrialização da carne suína. In: CONFERÊNCIA INTERNACIONAL SOBRE CIÊNCIA E TECNOLOGIA DE PRODUÇÃO E INDUSTRIALIZAÇÃO DE SUÍNOS, 2., 1996, Campinas. Anais.... Campinas: Instituto de Tecnologia de Alimentos, 1996. p.99-122.

SIMPSON, S.P.; WEBB, A.J. Growth and carcass performance of British Landrace pigs heterozigous at He halothane locus. Animal Production, v.49, n.3, p.503-509, 1989.

SMET, M.S.; PAUWELS, H.; BIE, S. Effect of halothane genotype, breed, feed withdrawal, and lairage on pork quality of belgian slaughter pigs. Journal of Animal Science, v.74, n. 8, p.1854-1863, 1996.

SMET, S.; BLOEMEN, H.; Van VOORDE, G. Meat and carcass quality in two pigs lines of different stress-susceptibility genotype and their crosses. Animal Science, v.66, n.2, p.441-447, 1998.

TAM, L.G.; BERG, E.P.; GERRARD, D.E. Effect of halothane genotype on porcine meat quality and myoglobin antioxidation. Meat Science, v.49, n.1, p.41-53, 1998.

TROUT, G.R. Contribution of the halothane gene to pse levels in australian pork. In: INTERNATIONAL CONGRESS OF MEAT SCIENCE AND TECHNOLOGY, 40., 1994, The Hague. Abstracts .... The Hague: ICoMST, 1994. p.44.

WARRIS, P. New developments in He preslaughter handling of pigs. In: CONFERÊNCIA INTERNACIONAL SOBRE CIÊNCIA E TECNOLOGIA DE PRODUÇÃO E INDUSTRIALIZAÇÃO DE SUÍNOS, 1., 1995, Campinas. Anais ... Campinas: Instituto de Tecnologia de Alimentos, 1995. p.81-107. 